\title{
Spiritual and Moral Education of Student Youth at University of Culture
}

\author{
Olga V. Pavlenko* \\ Khabarovsk State Institute of Culture \\ 112 Krasnorechenskaia Str., Khabarovsk, 680045, Russia
}

Received 12.01.2016, received in revised form 18.02.2016, accepted 25.05.2016

This paper analyzes the characteristics of student development at university of culture as creative people in modern higher education. The author defines the purpose of spiritual development and education of a person in high school, which is to help the future specialists to find their place in life, having mastered the profession, to understand their own destiny, to bring up spirituality and spiritual ideals. Special attention in this process is given to music education and folk pedagogy.

Keywords: education, upbringing, ideal, creativity, personality, culture .

DOI: 10.17516/1997-1370-2016-9-6-1427-1433.

Research area: pedagogy.

In our time we often hear bitter complaints about the low cultural level of the youth! Young people are blamed for lack of spirituality, being obsessed with mass culture. However, it turns out that many representatives of the "Generation Next" who strive for "high and true" accomplishments, are ready not only to get acquainted with the true art, but also for active work.

Such kinds of educational activities as education and upbringing should be inseparably linked for the formation of the individual integrity of the student at university, for full personal development and preparation for employment and social activities. That means that besides the process of learning, a student should be engaged in obtaining knowledge, skills and abilities, personal traits, moral and volitional qualities, should acquire a sense of citizenship, awareness of socially significant values. These all are the elements of the educational process. Modern higher education is directed to the development of creative personality, to the formation of a competent professional in the field of professional activities, to teaching the ability to adapt to the changing socio-economic conditions. Education as an organic part of the educational system creates conditions for the development of such a person, formation and self-affirmation. New state standards in higher education are focused on the graduates' general culture and professional competences. Therefore, the aim of the modern education system should be to prepare a professional and cultural student, possessing a certain worldview, capable of self-development and self-realization, well-developed abilities of thinking, professional and social creativity.

(C) Siberian Federal University. All rights reserved

* Corresponding author E-mail address: prorector-tv@hgiik.ru 


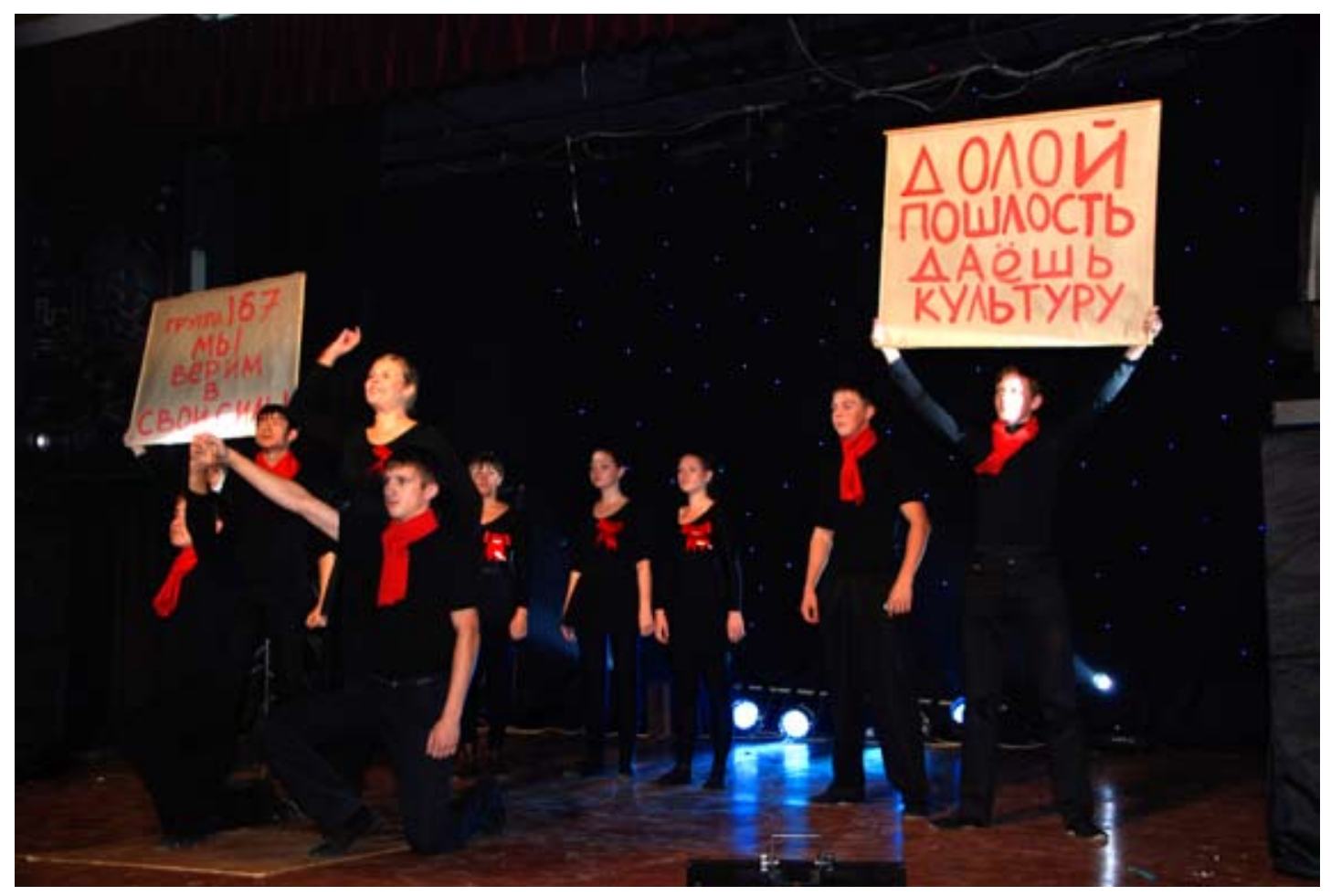

Patriotism and citizenship have to be brought up from the cradle. A major role in this process belongs to the entire system of education and training, and above all, to schools. The entire system of educational institutions, the media, museums, libraries, government; youth, veterans and other public organizations ought to exercise best efforts in this direction. Historical facts and historic figures have great power of moral influence. People without historical memory are doomed to degradation, whereas every Russian associates the concept of citizenship and patriotism with the necessity of the strong, powerful and prosperous Russian state.

The ideal final of the modern higher education is a spiritually rich and highly skilled person, having not only professional skills, but also the spiritual and intellectual potential. The purpose of spiritual development of a person in high school is to help future specialists during the professional development to find their place in life, to understand their own destiny, to form spirituality and spiritual ideals.

Spiritual, intellectual culture is a complex social phenomenon. Like any superstructural category, the spiritual culture characterizes (reflects) a particular way of life of the community and influences actively all forms of the society development. Though not providing direct, immediate impact on production or other technical indicators, spirituality affects the progress of society as a whole, and the individual in particular, forming such important personal qualities as morality, patriotism, establishing ethical criteria of life, developing the aesthetic tastes of the society members.

Once heated debate about what is more important in training students in higher education, education or upbringing, have already subsided. All scientists or at least the majority of them agree that the upbringing and education of the student should go not just parallel to each other, but in close unity. Institution training of high-end 


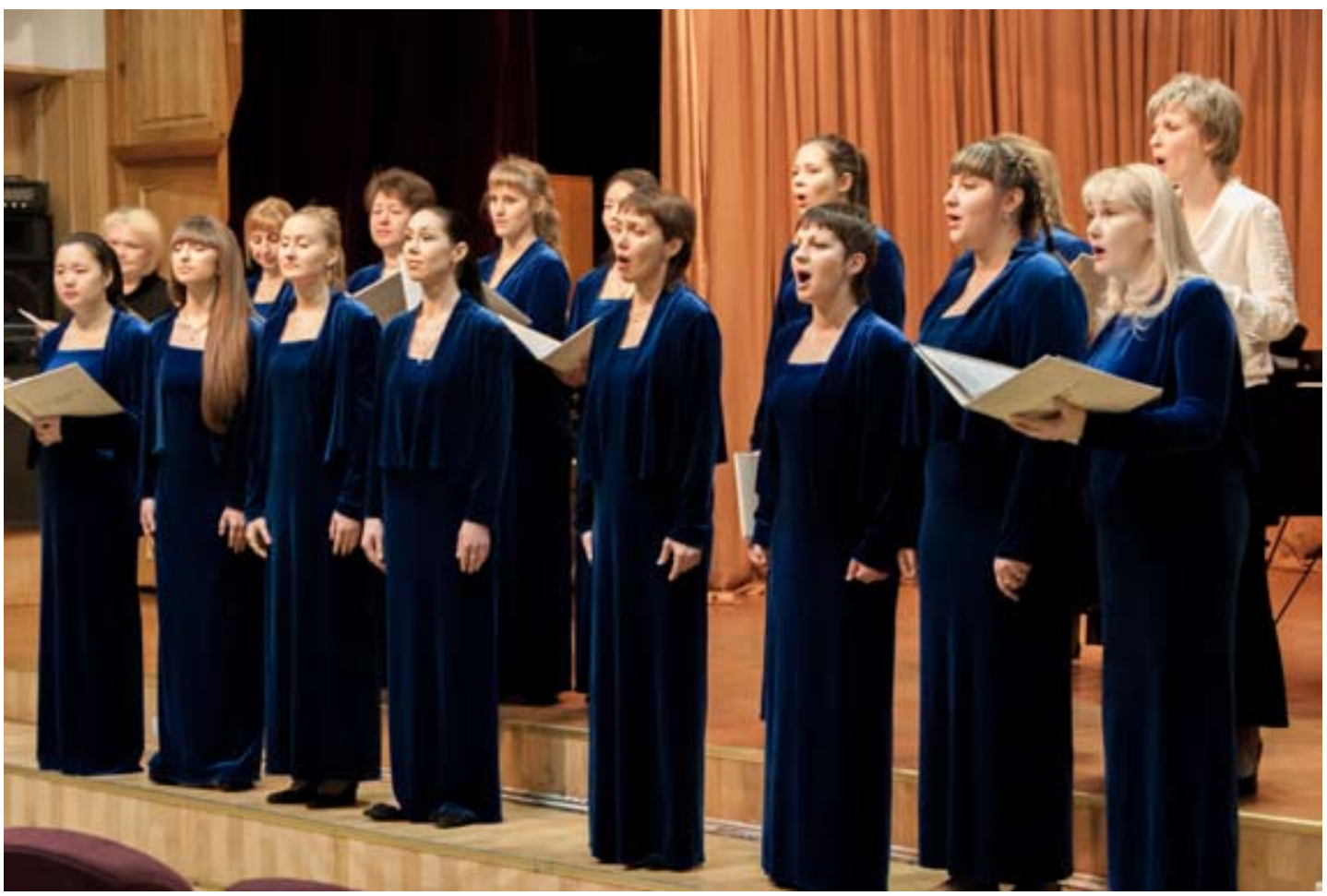

professionals is impossible without their spiritual development, without initiation into high moral ideals. Therefore, the synthesis of professional and spiritual education has to fill and permeate the whole educational process in high school.

A man finds it hard to develop personality independently in this lack of culture, moral decline and lack of well-established social ideals, so some instructors should appear here to help the young man. A teacher and a master must him-/herself demonstrate a spiritual potential, active creative thinking and unconventional approaches. The well-known postulate of that "only a person can raise another person" has not lost its relevance.

Inoculation of the spiritual ideals in the student environment should be based on an elaborate system of teaching in the fields of history, philosophy, religion, cultural studies, sociology, literature and special subjects. In the first place here are the teachers of these disciplines, who should form the students' moral and aesthetic ideas and attitudes, combined with various kinds of practical knowledge, skills and abilities, which altogether indicate a creative and constructive direction.

Unfortunately, the fact is that the necessary contact between the creative and theoretical departments in high schools of culture and art has not been achieved yet, their activities are not always coordinated, the relationships between them are often as if alienated. As a result of this estrangement, united in theory learning process is divided into two parallel, not merging with each other streams. Creative lecturers feel their monopoly in educational process due to the importance of special subjects taught. Unlike lecturers, who teach creative discipline, lecturers of theoretical subjects are usually well aware of the importance and role of science in the spiritual education of students. However, their professional habit of a purely academic way of thinking, of academic lectures often interferes with real educational process. Therefore, the courses are taught without taking into account the future 
profession of their students. There is a real "gap" between practitioners and theorists, but they both are equally guilty in creating this division.

The parallel orientation of the educational training on instilling spiritual ideals and skills makes us look for new and original forms of personal fulfillment.

Most of the students associate the concept of spirituality with an internal, invisible world of human. This "invisible" side can be seen and understood by studying human practical activities, by studying human relationship to society, which is revealed in concrete deeds, actions and in the educational activities. Religious faith is the highest form of knowledge, attitudes and beliefs of the student, the guarantor of his/her behavior and attitude to the world, God and themselves, the most important criterion of personal spiritual ideals.

The meaning of a person's life is closely linked with the consciousness. The mere word "consciousness" (con-scientia) is a complex manifestation of the spirit, own knowledge, in which the psychological experience is complemented by ideal images and reproduced in them. The problem of life meaning is tightly bound not only to plans for the future, but also to the purpose of existence.

Kindness is an integral part of spirituality. It awakens the conscience, which sooner or later stands up for justice, peace and happiness.

The incarnation of spirituality is the true realization of the ideal of beauty. Influencing the man without coercion, in a free and open way, beauty is able to overcome not only the routine, mousiness, selfishness, down-to-earth attitude, but also titanic pride, maximalism and extremism.

Genuine beauty is spiritual perfection, being embodied in the material, bodily incarnation, it transforming the earth matter, permeates it with divine light and color, sound and intonation, emotion and reason.
The magnitude of the emotional experience, going from musical influences, cannot be compared with the power, say, natural hunger. Nevertheless, the power of motivation for the music listener is so high, and even higher for the performing musician, that it captures the man fully, leaving no room for the perception of any other influences. For the long time the man has been repeatedly exposing him-/herself to the blows of musical influences. This "self-exposure" serves to the holistic, mostly spiritual needs of the individual.

The special role of music for an individual is associated with the personal communication through music with other people. Leo Tolstoy once said about music: "Music, like all arts, but music especially causes the desire to ensure that all people, more people participate in this enjoyment. Nothing can better show the true value of art: you are transferred to another person, want to feel through others".

The meaning of musical intonation as an important factor of musical and auditory activity is that it establishes a special relationship between music and the perceiving individual. Musical perception ensures the listener and performer achieve their individual aspirations and possibilities freely; as well as it provides listeners with a sense of protection from external influences of the world.

Experience in folk education, the formation of spiritual and moral thinking among all ethnic groups, nations and people is very rich. As the analysis of the traditional culture of education has shown, this experience is characterized by almost the same requirements to the quality of the personality in the system of educational and training means. This system is a kind of common (for all mankind) folk wisdom, the universal system of values, proven for centuries.

The most interesting aspect is influence of folk music on the process of musical thinking 
and education of the person, who represents the traditions and aspirations of the nation. Richness of folk music is generally recognized and validated in musicology by I.I. Zemtsovskii. The corresponding concepts - expressiveness, associative, image, content and semantic character are successfully related together.

Education at university of culture is based on national traditions and foundations of folk pedagogy. Such upbringing is a cornerstone in educating the head of the creative association, who would support the spiritual and moral origins of life, as well as in educating a person with strong ideas about the country and the patriotic feelings, shared by the folk band members.

Folkpedagogyhasalways putagreatemphasis on commandments. Leading commandment in this system is engraining patriotic feelings. It is no accident that patriotism, love for the region, for the motherland, where one was born, and for the country as a whole, runs through virtually all forms of oral folklore: fairy tales, heroic epics, songs, proverbs and sayings. This patriotic idea is central in the written monuments, both anonymous and of known authors. Patriotism is expressed not only in describing the heroism of people, but in the poetic descriptions of native wildlife, the glorification of the homeland, the condemnation of betrayal, cowardice and evasion of civic obligation. Patriotism has always been associated with certain personality traits, such as courage, bravery, valor, honor and dignity, even in relations with the enemy.

Next commandment of folk pedagogy is education of kindness and love for people: "Love thy neighbor as thyself for thy good will", "Honor thy father and thy mother, that thou may be well and that thy days will be long upon the land", "Woe betide those, who do no good to anyone".

The third commandment is education of diligence. People have always made fun of idlers, couch potatoes, loafers. Especially brightly this commandment is expressed in such popular sayings as: "Judge the trees by the fruit and people - by their deeds", "Water does not flow under settled stones", "He who would catch fish must not mind getting wet".

The harmony of the physical and mental development, their moral purity and aesthetic attitude towards life and art are connected to the improvement of many individual qualities and personality traits. The musical development and education are interconnected and are in constant communication here. Education contributes to development, and also determines the educational success.

The objectives and issues of the spiritual and moral upbringing set the choice of methods and instructional techniques of training.

All the musical education methods are used by the teacher as a system, an indivisible whole. A word brings to the perception and understanding of the content of the work, while music enhances the arising emotional experience. Music affects the senses and creates thoughts. And there is no thought without verbal expression. During training it is always necessary to remember that the musical images are so thin, flexible, ephemeral, that a lot of pedagogical tact is needed to avoid distorted impression of the music through explanation. The teacher should in contrast deepen the impression without taking the content away from the music itself. The speech preceding listening to folk music should be poetic, imaginative, and informative. As opposed to the instrumental music, the song as if tells about itself through the poetic text. Its often complex metaphors and stylistic turns require from the teacher a thoughtful explanation.

All the treasures, created by the artistic genius of peoples, open the variety of spiritual life for everyone. Without a sense of duty, honor, teamwork, citizenship, patriotism there is no spiritual wealth, there is no man in the true 
sense of the word and, of course, these qualities are inherent to the fully mature individual. But we shall mention that everything complicated is made up of simple, and higher feelings spring from elementary, from primitive at first emotions, the first direct movements of the human heart. Mastering the "ABC of feelings", i.e. the ability to love people around, to responds to others' joy and trouble, people naturally and gradually come from small things to large ones, including the ability of non just "memorizing" the moral norms of behavior, but organically absorbing them, to make them part of the "Self".

The well-being and happiness depend on how each person feels the people around, as they correlate their conduct with the interests of society. Emotional incivility in relation to people engenders selfishness, which is the main root of indifference. The reason for the immoral behavior of people is in an emotional and moral ignorance, which is connected with the general shabbiness of the spiritual world.

Individual freedom, including freedom of feelings, is a great benefit of our society. But this benefit can turn into evil, if the relationships between people are not guided by one of the purest and most noble sense: human empathy, feeling that around there are people whose interests and desires cannot agree with mine.

The subtlety of feeling, emotions, emotional and aesthetic relation to the world and to oneself depend on the culture of sensations and perceptions.

The vision and experience of the beauty in the surrounding world is one of the most important sources of understanding and experiencing the joy of living, the beauty of life, originality and uniqueness of the idea that one lives only in this time, a small period in the eternal life of the world, nature and beauty. We must teach students to cherish life, to cherish the person, to protect people and protect life. The finer is this sensitivity, the richness of its colors, the deeper is the young heart susceptibility to moral precepts, to the subtlest means of influence on the spiritual world.

Raising students' spiritual needs is a complex set of techniques, practical measures, methods, productive interaction of various departments and most importantly is creation of atmosphere, where students would feel comfortable to strive for the ideal.

\section{References}

Antonova, N.V. (1997). Lichnostnaia identichnost' sovremennogo pedagoga i osobennosti ego obshcheniia [Personal identity of a modern teacher and features of his/her communication], In Voprosy psikhologii [Issues of psychology], 6.

Akbaeva, A.M. (2003). Psikhologicheskie osobennosti studenchestva kak osoboi social'noi gruppy [Psuchological peculiarities of student as a special social group], 11.

Batishchev, G.S. (1995). Naiti i obresti sebia [To find and discover yourself], In Voprosy filosofii [Issues of philosophy], 3.

Berdyaev, N.A. (1993). Chelovek [A man]. Moscow, Respublika.

Bodalev, A.A. (1983). Lichnost' i obshchenie: Izbrannye trudy [Personality and communication: Selected works]. Moscow, Pedagogika.

Bodalev, A.A. (1988). Psikhologiia lichnosti [Psychology of personality]. Moscow, Izd-vo Moskovskogo un-ta.

Kondrina, I.V. (2000). Razvitie u studentov potrebnosti v samosovershenstvovanii professional'no vazhnyh kachestv [Development of students' need in self-developing professionally 
important traits], In Vestnik Kuzbasskogo tehnicheskogo universiteta [Vestnik of Kuzbass State Technical University], 4.

\section{Духовно-нравственное воспитание \\ студенческой молодежи вуза культуры}

\section{О.В. Павленко}

Хабаровский государственный институт культурь Россия, 680045, Хабаровск, ул. Краснореченская, 112

В предлагаемой статье анализируются особенности развития студента вуза культуры как творческой личности в современном выстем образовании. Автор определяет цель духовного развития и воспитания личности в вузе - помочь будущему специилисту при освоении профессии найти свое место в жизни, понять собственное предназначение, сформировать духовное начало и духовные идеаль. Особое внимание в этом процессе уделяется музыкальному воспитанию и народной педагогике.

Ключевые слова: образование, воспитание, идеал, творчество, личность, культура.

Научная специильность: 13.00.00 - педагогические науки. 